\title{
Human Dynamics of Effective Lean Team Cultures and Climates
}

\begin{abstract}
More organizations then even before are adopting or consider to adopt Lean Management; this trend, beyond manufacturing, can be seen as part of the drive towards operational excellence. While academic studies on Lean methods are widespread, research on effective behavior in Lean operations is still rare. To date there have been few scholarly studies that reported on behavioral predictors of Lean organizing. In this review paper we analyze them; careful search- and selection effort uncovered ten empirical Lean studies with a teambehavioral focus; they are methodologically diverse and offer various lenses. Given this small set of original studies, we supplemented our review of Lean team studies with relevant results of the much older and more established team-effectiveness literature. Nine Lean team human dynamics were uncovered, consisting of affective, behavioral and/or cognitive factors that build upon and reinforce each other in a delicate balance. It appears that a Lean team culture is hand-crafted, over time: when team members engage in Lean practices that are helping them to reflect on their own work habits so that they can improve their routines. Moreover, variables that figure prominently in effective team contexts, such as 'voice behavior' or customer-related output variables, have not been included in the reviewed Lean team studies. Thus, this systematic review of the available empirical Lean team behavior studies opens up new research paths for testing the various theoretical linkages between effective Lean management, group behavior at the shop-floor level and organizational/group culture/climate theory, including enablers of effective Lean work-group behavior.
\end{abstract}

Keywords: Lean Operations, Team/Group Effectiveness, Culture/Climate. 


\section{INTRODUCTION}

Lean Management is gradually returning to the management (research) agenda, particularly in the growing field of change management. The general focus of prior Lean research has been on operational instruments. Now, however, authors of the available toolfocused studies are calling for a better understanding of the human and behavioral side of effective Lean organizing (Shah and Ward, 2007), including the cultures that enable Lean success (Shook, 2010; Zu, Robbins, and Fredendall, 2010). Indeed, a broad behavioral focus on Lean is needed; through a Lean lens, non-managerial employees are seen as experts in improving daily operational processes and work habits (Bicheno and Holweg, 2009; De Lange-Ros and Boer, 2001; Tucker, Edmondson, and Spear, 2002). Allowing these employees to spend time on continuous improvement is seen as essential for firms to thrive (De Lange-Ros and Boer, 2001; Tucker et al., 2002).

Also Hackman and Wageman (1995) had noted that research focused systematically on behavioral change in Lean settings was very rare; the field is almost entirely based on anecdotal evidence. They called for a new wave of behavioral research to fill this void. The purpose of this paper is to review the available empirical studies that have examined Lean team behavior. Even though the number of serious studies on this score are not large, this review does offer new insights on how effective Lean work-floor teams work, with an emphasis on their behavioral dynamics which necessarily must addresses the thorny and surprisingly little researched topic of culture/climate change.

This review is structured around two core questions: 1) What type of human dynamics characterizes effective Lean teams? And: 2) How can team cultures/climates become effective Lean team cultures/climates? Given our aim to draw up a multidisciplinary research agenda, we integrate theory and research from disparate literatures, spanning the dynamics of smallgroup research, leadership, organizational culture and climate, and operations management 
(OM). The core of this review of empirical Lean team findings entails a comparison of the Lean-specific findings with known factors in the team effectiveness literature (e.g. Bendoly, Croson, Goncalves, and Schultz, 2010; Cohen and Bailey, 1997; Hackman, 1987; Kozlowski and Ilgen, 2006; Marks, Mathieu, and Zaccaro, 2001; Mathieu, Maynard, Rapp, and Gilson, 2008; Salas, Sims, and Burke, 2005; Salas, Stagl, and Burke, 2004). The latter literature or theory is namely much older and larger and, in our view, underutilized by most Lean scholars. The overarching review goal is to offer a fundamental rethink of the behavioral processes underpinning Lean team effectiveness and, in so doing, spur a new stream of practice-relevant Lean team research to advance new theory.

This paper's Lean work-floor team focus is important because: 1) most organizations start their Lean implementation journey on the shop floor (Liker and Morgan, 2006); 2) if the behavioral dynamics at this level of aggregation were to be better known, many of the failures in Lean implementation could be prevented (Ballé, 2005); and 3) workplace teams are foundational for improving the performance of firms. It is a crucial starting point for successful Lean operating (Boer and Gertsen, 2003; Edmondson, Dillon, and Roloff, 2007). As the context of each workplace group is unique, this needs to be taken into consideration. However, there are overarching behavioral patterns to be identified about the people working in Lean teams. This review paper aims to help derive such patterns, so that they become easier to manage, eventually.

\section{Lean Management and High Performance}

The increasing adoption of Lean Management in diverse kinds of organizations reveals a trend towards strategies focused on operational excellence. Over time, different work practices have been associated with Lean Management, such as Continuous Improvement programs (Kaizen) and Total Quality Management (TQM) (Shah and Ward, 2003). Shah and 
Ward (2007: 791) propose the following definition of Lean: “An integrated socio-technical system whose main objective is to eliminate waste by concurrently reducing or minimizing supplier, customer, and internal variability." "In developing a Lean orientation to management, the following five fundamental rules have been noted (Bicheno and Holweg, 2009; Emiliani, 1998; Hines, Found, Griffith, and Harrison, 2008: 4; Hines, Holweg, and Rich, 2004; Womack and Jones, 2003):

1. Specify what does and does not create value from the customer's perspective, rather than from that of the individual firm or specific functions, departments, or teams;

2. Identify all the steps necessary to produce the product/service across the whole value stream, in order to highlight non-value-adding waste, such as waiting time;

3. Ensure that those actions that create value flow without interruption, detours, backflows, waiting or scrap;

4. Only make what is requested (i.e. 'pulled') by the customer;

5. Strive for perfection by continually removing 'waste' at work as it is uncovered.

Whereas the first four Lean principles may seem achievable merely through analytical methods, they do assume that in practice everyone in a given work setting is actively engaged in Lean and oriented toward continuous operational improvement. Furthermore, the fifth principle requires employees and managers to continuously monitor for non-value adding routines in order to improve work practices. Lean Management requires the collective establishment of an attitude of 'continuous improvement' as well as matching behaviors (Busk Kofoed, Gertsen, and Jørgensen, 2002; Hines et al., 2004). Continuous improvement of work processes in order to increase customer value is the ultimate purpose of Lean production

\footnotetext{
${ }^{1}$ Although Shah and Ward defined Lean from a conceptual and operational angle, their definition negates the idea that firms may add value by satisfying the increasingly varied customer's wishes (Hines, Holweg, and Rich, 2004).
} 
practices. Despite the fact that the behaviors of the key actors involved in Lean are the key to its success, they have received much less attention than the Lean tools and techniques with which they are supposed to work.

The present review focuses only on work teams that regularly meet face-to-face (daily or weekly), as opposed to virtual teams that operate in a more dispersed fashion (Maznevski and Chudoba, 2000). Since the empirical literature on work teams that have adopted Lean principles is not abundant, our review is quite inclusive. We incorporate a wide range of teams, spanning different skill levels and levels of task complexity (De Dreu and Weingart, 2003). Accordingly, in this review, we shed light on the human dynamics involved in workgroups that have embraced Lean.

Scholars normally associate Lean with high team performance (Shah and Ward, 2003). Team performance is a term often used for the productive output of a team, irrespective of how the team achieves its performance levels from a behavioral angle (Edmondson, Dillon, and Roloff, 2007; Salas et al., 2005). In research on small group effectiveness the term team effectiveness is commonly identified and used as the ultimate outcome variable (see, e.g., Cohen and Bailey, 1997; Hackman, 1987; Kozlowski and Ilgen, 2006; Marks et al., 2001; Salas et al., 2005; Salas et al., 2004). In these studies team effectiveness tends to be operationalized to include not only team performance, but also how the team interacted to achieve this outcome (Salas et al., 2005: 557). In the context of the so called Input-MediatorOutput-Input (IMOI) model (Ilgen, Hollenbeck, Johnson, and Jundt, 2005), various researchers have noted that team functioning is an ongoing, iterative human phenomenon (Day, Gronn, \& Salas, 2004; Ilgen et al., 2005; Kozlowski and Ilgen, 2006; Mathieu et al., 2008; Uitdewilligen, Waller, and Zijlstra, 2010). This is certainly the case within Lean workplace teams that are explicitly charged with continuously improving their own 'rules of the game,' including for instance their work standards, team structure, communication norms, 
associated practices and routines. For the purpose of this review we consider as mediating type factors those that may also explain the variance in team performance (Ilgen et al., 2005).

\section{Searching for Research on Lean Teams}

We conducted a thorough systematic search using the Web of Science and Scopus. In both engines we explored combinations of the following search terms: Lean, as well as the theoretically closely related terms Continuous Improvement, TQM, and Kaizen, combined with Culture, Climate, or Behavior (for example: Lean climate, Lean culture, Lean behavior, etc.). Criteria for publication selection in the initial sample were: use of the search terms in the title, abstract or keywords, and a focus on organizational settings. This sustained query allowed us to assemble an initial sample of 709 Lean writings varying in organizational context, level of analysis and quality. We then narrowed down this sample based on very specific inclusion and exclusion criteria and checked the back references as well as the forward citations of the final sample (in doing so we followed the review advise given by Wolfswinkel et al., in press). ${ }^{2}$ In the end, we found only ten high quality empirical papers published between 1995 and 2010 (see Table 1). Seven of these dealt with manufacturing firms and three studies were carried out in other type of firms.

Insert Table 1 about here

It is noteworthy that the ten selected studies employed a variety of methods, ranging from the usual survey and interviews, to participant-observation, action research and a videotaped

\footnotetext{
${ }^{2}$ We included studies that passed the following criteria: empirical nature, focus on the for-profit sector, high-end journal ranking (based on a minimal 1.000 five-year Journal Citation Report of Web of Science and a minimal 0.050 SCImage Journal and Country Rank of Scopus), and a team (or individual) level of analysis (as opposed to organizational, industry or national level of analysis). The precise selection procedure is available on request.
} 
optimization task within the field. One study reported on a longitudinal team survey that tracked the changes in team climate during two Lean implementation phases (see, Mullarkey, Jackson, and Parker, 1995). We thus feel confident that our relatively small sample is still methodologically diverse, providing various lenses to the human side of Lean teams; an initial analysis of the ten studies found that the research contexts varied enormously. Some of the research was carried out on high-performing teams, others on low-performing Lean teams. Some of the studies were of mature Lean teams, while others reported on teams that were just starting to become a Lean team. Despite the fact that some of the ten studies lack conceptual, operational or situational precision, we were able to distinguish human dynamics that were treated by these ten studies. Human dynamics include patterns of intra-team or interaction behavior, including affective and cognitive states between team-members, as well as the team leader (DeChurch and Mesmer-Magnus, 2010; Ilgen et al., 2005). Such internal team patterns are largely invisible with the naked eye to those working outside the team. We define these 'intra-team dynamics' as follows: all mediating or moderating human factors that transform external team inputs into collective team outcomes. Given the small set of empirical Lean team studies, we thus supplement our analyses of Lean team effectiveness with relevant results of the much more established team-effectiveness literature. Given that Lean workplace teams strive for perfection (see, e.g., Womack and Jones, 2003), we assumed that Lean teams develop in ways that are similar to otherwise highly-effective teams.

\section{HUMAN DYNAMICS WITHIN LEAN TEAMS}

We turn now to presenting the human factors examined in the empirical studies. For each factor we summarize the studies' findings, and link these insights to what we know from the team-effectiveness literature. These linkages provide additional support for new intraLean team propositions. 


\section{Psychological Safety}

This motivational team factor was studied in five of the ten selected papers. Compared to similar non-Lean plants Rothenberg (2003) found more trust at NUMMI, including a more collaborative culture; Rothenberg stressed that without trust no employee will contribute towards the improvement of work practices. Bunderson and Boumgarden (2010) surveyed a sample of 40 teams and detected a significant link between psychological safety and learning behavior; this link was mediated by information sharing as well as conflict frequency. Additionally, Zeitz et al. (1997) found no significant increase in 'trust' during the course of TQM implementation. In their longitudinal study, also Mullarkey et al. (1995) saw no significant increase in 'trust in co-workers.' Hence, interpersonal trust levels do not seem to appear to increase over time in Lean teams. One interpretation could be that an already fairly high trust level may be needed before Lean practices get underway. Indeed, Jackson and Mullarkey (2000) found that Lean teams have a significantly higher level of co-worker trust than similar non-Lean teams; clearly, the trust-levels of Lean teams might or might not improve over time, depending on both its original base-level and other team dynamics.

From Salas et al.'s (2005) critical review of numerous studies of small-group effectiveness predictors we learn that 1) the more the mutual trust within teams, the more likely team members will accept mutual monitoring of team member's performance; and 2) mutual trust supports information sharing among team members. Moreover, in psychologically safe Lean teams, members feel free to discuss improvement suggestions and learn from mistakes in order to remove waste and innovate in work practices (Baer and Frese, 2003; Edmondson, 1999, 2011). This happens even if the members lack confidence about their own tacit knowledge about their work (Siemsen, Roth, Balasubramanian, and Anand, 2009). Baer and Frese (2003) found that organizations with a high climate for psychological 
safety had a significantly higher return on assets than firms with a low level. Thus, the first proposition for future Lean team research is: High Lean team performance is a function of team members feeling psychologically safe to discuss errors or ideas for improvement. At the same time, when members of Lean teams feel charged not only to maintain but also to cocreate a high level of psychological safety, this may lead to high Lean team performance. To be sure, other people and a multitude of factors in and around teams play a role in creating and maintaining a psychologically safe work environment. Insofar as various academic Lean studies have addressed them, they will be covered later in this review.

\section{Team Cohesion}

The notion of team cohesion was included in five of the ten Lean-team papers. Their conceptual and operational definitions focus not only on the quantity of social interaction between team members, but also on their quality. In the studies of Mullarkey et al. (1995) and Jackson and Mullarkey (2000) cohesiveness was taken as "the extent to which respondents felt that team members worked well together" (2000: 238; 1995: 70). Mullarkey et al. (1995) found that clustering teams in U-shaped assembly areas led to significantly more team cohesion. Jackson and Mullarkey (2000) queried 242 Lean team members and found that a greater degree of task interdependence led to more frequent social contact within multiple Lean teams. This also led to frequent quarrels and less cooperation among team members, and group cohesiveness was shown to be significantly lowered. Also, Kauffeld (2006) reported using a video-analysis method - significantly more negative criticism in 44 teams that implemented a self-directed mode of working. Delbridge (1995) saw that JIT-related work pressure and subsequent intra-team self-policing led to 'considerable tension' and more arguments among workers, especially in the form of blaming other sub-groups on the line. Zeitz et al. (1997) reported no enhanced social cohesion after TQM program implementation. 
Based on the Lean team findings to date it is tenable that before effective Lean team production can take place social-cohesion levels must surpass a certain threshold. Nevertheless, the reported findings to date also suggest that Lean team cohesiveness may be lower in the short term (due to a Lean team's initial struggle to change things in its non-value adding tasks), but that it may improve during more advanced stages of Lean implementation (Mullarkey et al., 1995). It is quite remarkable that none of the Lean team cohesion studies have looked at the link between team cohesion and employees' perceived effectiveness of the change management approach taken. A poor approach to change may have two contradictory effects on team cohesion: Team members engage in more frequent discussions, leading to opportunities for conflict and lower cohesiveness. On the other hand, Lean team members may develop greater team cohesion due to bonding against a 'common enemy' (e.g. the managers or advisors of the change program).

Team-effectiveness studies tend to examine team cohesion as a positive motivational variable (Chin, Salisbury, Pearson, and Stollak, 1999; DeChurch and Mesmer-Magnus, 2010; Kozlowski and Ilgen, 2006; Mathieu et al., 2008). Effective teams are known to have greater interpersonal cohesion and pride, as well as a greater sense of working on a collective task. Yet, social psychologists have pointed to the risk involved in highly cohesive teams: i.e. groupthink, which often leads to operational errors (e.g. Bendoly et al., 2010). Hence, when members of a Lean team conform to a certain mindset with fixed and narrow assumptions, this might hold back any further performance improvement or learning (as shown within a sports team by Rovio, Eskola, Kozub, Duda, and Lintunen, 2009). In highly cohesive teams, a sense of criticality may be lacking in the way they handle their work and their co-workers. To be highly cohesive and tackle groupthink at the same time is likely to require a medium level of psychological safety: in order to air feelings. And this needs to be promoted by the team leader (Moorhead, Neck, and West, 1998). Accordingly, we propose that members of high- 
performing Lean teams feel a moderate amount of team cohesiveness. In the teameffectiveness review of Mathieu et al. (2008: 462) it is noted that progress towards goal accomplishment may function as 'dynamic inputs' to emergent states, such as team cohesion. In other words, a Lean team may, under certain circumstances such as for instance team success, experience an elevated level of team cohesion, but that state might be temporary.

\section{Conflict Management}

Five of the ten papers addressed conflicts within Lean teams. Zeitz et al. (1997) showed that good communication, including solid conflict resolution, was significantly enhanced during TQM implementation. Bunderson and Boumgarden (2010) as well as Delbridge (1995) showed that frequent intra-team conflicts, especially territorial, are not likely to result in effective outcomes. They demonstrated that conflicts negatively mediate between team structure and learning in teams. It was shown that if a team is well-structured, members are more likely to learn from work experiences, including conflict. In terms of effectively solving problems at work, Kauffeld (2006) found that compared to traditional teams, self-directed teams showed more 'professional competence' in linking problems to solutions; video-analyses of the teams found that the self-directed teams were able to rephrase problems much better. Bessant et al. (2001) had already noted that more mature Lean teams readily take the initiative to both identify and solve issues; they make addressing problems part of their normal working culture.

These findings on conflict in Lean teams are consistent with what we already know about conflict resolution in general (see, for example, the insights derived from both Ilgen et al., 2005; Kozlowski and Ilgen, 2006; Marks et al., 2001); the team-effectiveness literature claims that team conflicts seem generally ineffective, yet the outcomes depend on the specific ways of handling a dispute (Tekleab, Quigley, and Tesluk, 2009). If team members are used 
to getting and giving feedback, effective conflict management occurs (Ilgen et al., 2005). Indeed, Kozlowski and Ilgen (2006) documented how constructive feedback led to learning behavior and goal accomplishment. Feedback sheds light on discrepancies (such as poor product or service quality) and reveals, for those who are willing to confront and solve problems, possibilities for improvement. Such feedback must not take the form of blaming (Delbridge, 1995), which prevents constructive conversation and jeopardizes team cohesion and psychological safety (Bendoly et al., 2010). Hence when conflict occurs in Lean teams, providing it is dealt with constructively, improvement or learning is likely to take place, including exploration of new solutions. Equally, the negative impact of a team conflict depends on whether the conflict's nature is task- or process-related (cognitive), or relational (affective) (Jehn, 1997; Tekleab et al., 2009; Zaccaro, Rittman, and Marks, 2001). Delbridge's (1995) study reported an affective, relational type conflict: blaming others for failure. Indeed, high levels of process or relational conflict have shown to be detrimental; whereas a moderate amount of process conflict may lead to higher efficiency and task conflict is likely to improve the quality of team decision making (Jehn, 1997).

The above observations resonate with recent work in the emerging area of Positive Organizational Behavior. After a conflict has emerged, forgiveness (Quick, Cooper, Gibbs, Little, and Nelson, 2010), self-reflection (Bendoly et al., 2010) and motivation to learn from one another can be transformative (Quick et al., 2010). In other words, if team conflicts are dealt with in constructive ways, team learning may occur. Edmondson (1999) suggested that continuous team learning behavior is centred on potentially conflicting activities such as seeking team feedback, discussing errors and seeking feedback from customers (Bartezzaghi, Corso, and Verganti, 1997; De Lange-Ros, 1999). Van Dyck, Frese, Baer and Sonnentag (2005) found evidence that openly discussing errors and learning from them enhances financial performance. Clearly, effective conflict resolution within Lean teams is needed so 
that effective closure, including team learning, is secured. Despite this high convergence in findings regarding team conflict, there are still ample new-research possibilities, for example in terms of the character of incidents that occur in Lean teams and its effects on team performance. It is likely that effectively resolving task conflicts leads to higher Lean team performance while only moderate amounts of process conflicts may lead to higher Lean team performance. Relational conflicts, on the other hand, may dampen Lean team performance. Moreover, the more constructive feedback members of a Lean team give and get, the higher their team's performance. Coaching members of embarking Lean teams on how to identify and handle conflicts in a constructive way may aid them to do well, in addition to training their feedback and constructive discussion skills.

\section{Team Member Support}

The idea of team member support was included in five of the ten Lean team studies, although with conflicting results. Three studies found an increase of team member support due to Lean implementation. For example, Mullarkey, Jackson and Parker (1995) reported a significant increase of such support after their Lean implementation. Investigating a range of organizational citizenship behaviors (OCBs, including helping others with work-related problems or team member support), Godard (2001) established a significant link to various Lean practices (such as quality management, team-based work systems, regular information sharing and quality circles). Rothenberg's (2003) analysis of the shop floor at NUMMI, characterized as egalitarian and collaborative, found an increased access to member support. Nevertheless, two studies reported otherwise: Jackson and Mullarkey (2000) found that in both Lean and non-Lean teams, team member support was linked to low job satisfaction. Delbridge (1995) observed that workers spotted and helped to fix their colleague's mistakes in order not to be held accountable by their leader for others' faults. However, in both studies 
the support provided by the team leaders and their higher-level managers was found to be inadequate; they might have role-modeled the low level of intra-team member support they found. In other words, the Lean-implementation studies provide an initial argument for an increase in team member support, but only as long as managers act in support of the team members. Hence our proposition is: In Lean implementation settings, high team leader support is likely to lead to higher levels of Lean team member support, which in turn predicts high Lean team performance. The latter part of this proposition is based on the generic teameffectiveness literature.

Of interest here is the parallel idea of back-up behavior (see, e.g., Marks et al., 2001; Salas et al., 2005), defined as task-focused helping behavior between team members (Seers, 1989). In order for this back-up behavior to take place, team members must engage in mutual performance monitoring (Salas et al., 2005), so that they know where and when back-up is needed, and can take the appropriate action if it looks as if the team may not reach its targets. Yet, back-up behavior has been shown to be counterproductive, especially in Lean teams with an evenly distributed workload among its team members: team members' helping behavior dampened the time they had available for their own tasks, resulting in inefficiency (Barnes et al., 2008). Thus, when Lean team members adopt much back-up behavior they may only be fixing symptoms, instead of solving the underlying problems, e.g. by applying the 5-timeswhy rule of thumb (see also Bicheno and Holweg, 2009; Imai, 1997; Shingo, 2007). In other words, a lot of within-team support may be a sign that a team is not doing well; it may detract from their potential performance (see, Barnes et al., 2008) and may prevent them from learning about the root-causes of the issues that come up. This lack of learning and associated lower performance goes against the grain of Lean's continuous improvement ideology. The upshot of this complex admixture of countervailing tendencies is that it is unlikely that backup behavior occurs much in mature Lean teams due to their already fairly optimized work 
processes. Hence: 1) High-performing Lean teams experience a moderate level of team member support; 2) In high-performing Lean teams back-up behavior occurs, but only in unforeseeable or incidental circumstances; and 3) A high level of back-up behavior within Lean teams is associated with a lowering of team performance.

\section{Performance Monitoring}

Three Lean-team case studies addressed task-focused 'performance monitoring'. Rothenberg's (2003) analysis of NUMMI noted that Lean team workers are particularly data driven, controlling their work based on reliable, real-time performance indicators: "Lean plants tended to have a greater number of water and energy meters in critical locations, were more likely to chart and post water and energy data on the departmental level, and posted this data more often" (Rothenberg, 2003: 1795). Indeed, the workers at NUMMI were trained to read charts and graphs for the effective analysis of production data. Bessant et al. (2001) reported that employees in daily team meetings discussed work issues, progress and targets, and engaged in various other forms of progress monitoring and knowledge capturing. As a result of this reflection on performance data, team members frequently recognized that change was needed. Delbridge (1995) observed a case where 'individual performance targets' for each worker and team leader were employed. An intra-team quality control function and high managerial pressure spurred the teams to develop new norms. Peers would put pressure on their low-performing members to improve their quality (Delbridge, 1995). Although the three cases all suggest that Lean teams must adopt performance monitoring for purposes of performance improvement, its relation to Lean team performance is not yet firmly established.

In the team literature we do find compelling evidence for monitoring progress toward goals (Marks et al., 2001): Based on effective continuous performance feedback, an effective team is likely to feel the need to continuously improve their work practices. A team's need for 
on-going adaptation, based on iterative performance cycles, brings into play another generic team factor: adaptability (Kozlowski and Ilgen, 2006; Salas et al., 2005). Members of effective workplace teams are expected to learn from each other and effectively deal with change (Uitdewilligen et al., 2010). Although Lean tends to evolve into carefully prescribed, standardized work processes, unanticipated events do occur regularly. Dealing with such deviations may lead to adaptation to a new situation. A typical Lean example is the use of an Andon-cord for highlighting an error that requires immediate repair (Stewart and Raman, 2007). During and after these moments a team is supposed to learn from the event and then fix it, possibly by adjusting a part of the standard work routine. On a daily basis a Lean team is supposed to discuss these 'errors' and their corrective, both temporary and more permanent type of actions. Hence we propose that: High levels of performance monitoring leads to high levels of Lean team learning and as a result to high Lean team performance. In other words, members of highly performing Lean teams seem to adapt their behavior quite readily after self-interpreting a regular stream of performance data. Members of effective Lean teams see regular discussions of their team's performance level as chances to further optimize their added value, and thus their on-going team performance. How exactly the performance dashboards come about in operational teams might very well make a difference here; Wouters and Wilderom (2008) showed that a high degree of employee involvement in designing their own team's performance measurement tools enhances both team trust and performance levels.

\section{Information Sharing}

In four of our corpus of ten studies information sharing was suggested to be a key characteristic of Lean workplace teams. Bunderson and Boumgarden (2010) showed that more structured teams tended to share more information, which in turn affected a team's learning orientation. At NUMMI, hourly workers were found to participate in suggestion 
programs and problem-solving circles (Rothenberg, 2003). Moreover, Bessant et al. (2001) documented a problem solving process and the use of appointed contact persons (for each type of occurring problem) within one of their six case companies. Delbridge (1995) described Lean-typical daily pre-production team briefings where tacit information and knowledge exchange took place. In these start-up meetings the less effective workers did not actively share information; they were simply passive attendants. It therefore seems that Lean teams are significantly more effective when all team members engage in sharing improvement oriented work-related information.

Previous research on highly effective teams has also shown that members share a relatively large amount of information (see, e.g., Kozlowski and Ilgen, 2006; Salas et al., 2005). In each firm there is a vast store of tacit and local knowledge, which seems particularly well exploited in a Lean mode. It is worth studying how extensively Lean team members share tacit kinds of job- and/or team-level information (including own ideas on how new or persisting work interruptions occur and might be solved). We would expect that in Lean teams such intra-team sharing of work-related information (that in non-Lean teams remain tacit) may have a performance enhancing effect. Moreover, effective Lean teams will typically have developed one or more simple structure and/or daily routine for the purpose of optimal information sharing, so that all team members are able to continuously work to full capacity. Hence, we propose that: When Lean team members regularly share various types of work-related information (e.g. in pre-work meetings), it will lead to higher Lean team performance.

\section{Innovating}

Three of our studies addressed innovating as a behavioral dynamic in Lean teams. Based on a survey of workers, Zeitz et al. (1997) claimed that 'innovation' improved 
significantly over the course of a TQM program. Bessant et al. (2001) reported on a case in a mature Lean work setting where both individuals and teams take time during their working day to experiment and develop new ideas, leading to entirely new-to-the-world procedures and practices. In addition, Kauffeld's (2006) team task video analyses showed that compared to traditional teams, self-managed team members were more self-competent, in the sense they were more improvement- and innovation-oriented while solving the task at hand. Thus, when a team is effectively engaging in Lean, team members show a high level of change orientation in terms of both continuously improving and innovating work practices.

Not long ago Toyota's president Watanabe stated that it was time to expand incremental CI ('Kaizen') and to make more radical improvements ('Kakushin'): “While trying to come up with incremental improvements, many people come up with revolutionary ideas. (...) I am only trying to get people to make the leap from incremental improvement to radical improvement wherever possible" (Stewart and Raman, 2007: 82). While it took Toyota several decades to ignite radical improvement, revolutionary ideas may also spring from incremental improvements, and they may need to be taken more seriously, given the more competitive landscapes of most older businesses (such as those in the automotive industry) today. Calantone, Cavusgil and Zhao (2002) show that a learning orientation (for instance knowledge sharing and being open to criticism) increases firm innovativeness. Moreover, it was found that Lean has a direct influence on employee's innovation orientation (Santos-Vijande and Álvarez-González, 2007). In other words, there is initial evidence that the continuous improvement efforts of a high-performing Lean team lead to a mindset with a high degree of innovativeness.

\section{Organizational Goal Commitment}


Two of the ten studies dealt with organizational goal commitment within Lean teams. Bessant et al. (2001) noted, in three of their six cases, that in advanced Lean firms, employees show a high level of awareness of both company goals and strategic performance measures. In contrast, Delbridge (1995) observed production workers in an ineffective Lean team distancing themselves from the goals of the organizations. They ignored discussions, company-uniform prescriptions and refused to participate in improvement initiatives, openly showing a lack of organizational commitment. Hence, Lean team studies provide only limited support for the idea that goal commitment is a behavioral dynamic of Lean significance.

Goal-setting theory (Locke and Latham, 2002) may help to further analyze the importance of organizational goal commitment to Lean teams. Lean as an organizational goal tends to be set by higher-level managers (Kanji, 2008). According to the goal-setting theory, employees must first understand the importance of becoming Lean and believe they are able to achieve this goal (high team- and self-efficacy). This will make them more committed to the Lean goal, which in turn may lead to significantly higher performance (Locke and Latham, 2002). In addition, workers' willingness to commit to Lean goals originates from satisfaction with past organizational change programs (see also Bordia, Restubog, Jimmieson, and Irmer, 2011; Elias, 2009; Locke and Latham, 2002). In sum: When Lean team members show high organizational commitment towards the company's strategic Lean goals high Lean team performance is likely to follow. High satisfaction by Lean team members with previous organizational change programs moderates the link between positive attitudes towards a changeover to Lean and organizational goal commitment.

\section{Team Leadership}

Team leaders are generally considered key actors in any team's effort to attain performance enhancement (Zaccaro et al., 2001), so we were surprised that only two studies 
in our corpus dealt with team leadership. In Delbridge's participant observation study (1995) team leaders monitored the team performance in order to catch opportunities for improvement. One team leader was pro-active, and tried to create work pressure by speeding up the line or controlling the radio switch 'when workers had time to chat.' This was counterproductive as workers felt exploited and team performance levels went down. In this case, the team leader had felt increased pressure from higher-level managers to improve the productivity. Ooi et al. (2008) concluded that instead of pressuring team members, it is a Lean leader's task to stimulate his or her direct reports to express their ideas, thereby creating in effect non-managerial employee participation.

In general, 'team leadership' is seen as one of the Big 5 determinants of effective teamwork (Salas et al., 2005). The impact of a team leader should be clearly differentiated from higher-level managers who play a more distant, strategic role in a team's daily practice (DeChurch, Hiller, Murase, Doty, and Salas, 2010). A team leader has a direct effect on human team dynamics, for instance through their on-the-spot reinforcements of new or improved customer-focused work practices and intermediation before quarrels escalate into conflicts (Zaccaro et al., 2001). A recent review conducted by Morgeson, DeRue and Karam (2010) echoes well what can typically be found in Lean teams: team leaders affect the social climate; monitor team performance; take appropriate action when results are lagging behind; notice continuous improvement opportunities within the team; acquire team resources; and encourage autonomy. In addition, team leader support intensifies employees' perceived organizational support (Rhoades and Eisenberger, 2002). Conversely, as shown in Delbridge's qualitative case, a lack of this perceived leader support had negative effects on workers' morale and performance. In order to be effective, a team leader's support may even need to be challenging to a team's extant assumptions, delivered while role-modeling care for their team members (Morgeson et al., 2010). The transformational leadership style, moreover, 
has been shown to be associated with a team's proactive improvement-oriented behavior (mediated by the establishment of favorable interpersonal team norms) (Williams, Parker, and Turner, 2010).

Building on the foregone analysis of the need for 'wise' leadership, we propose: The explicit monitoring of team performance by Lean team leaders is likely to lead to high Lean team performance only if such team leaders have empowered their team members to express their improvement ideas and if they show a transformational leadership style.

\section{Reflecting on the Human Dynamics within Lean Teams}

Our review resulted in a set of nine human dynamics and related propositions. In further scrutinizing the intra-team dynamics, one may cluster the factors involved into three types of human team dynamics: affective, behavioral and cognitive (see, e.g., Bosch-Sijtsema, Fruchter, Vartiainen, and Ruohomäki, 2011; DeChurch and Mesmer-Magnus, 2010; Ilgen et al., 2005; Kozlowski and Ilgen, 2006; Marks, et al., 2001; Salas, Cooke, and Rosen, 2008). In the 'affective' category we include those human dynamics that capture "motivational tendencies, relations among team members and affective reactions" (Kozlowski and Ilgen, 2006: 87). The 'behavioral' category constitutes "what teams do - their actions to strive toward goals, resolve task demands, coordinate effort, and adapt to the unexpected" (Kozlowski and Ilgen, 2006: 95). Also, we categorize those human dynamics that guide "taskrelevant interactions among team members" as instances of the 'cognitive' class (Kozlowski and Ilgen, 2006: 81). In other words, in order for team members to behave in effective Lean ways (e.g., sharing information, monitoring performance, innovating and supportive team leadership), they must be in a positive 'affective state' (e.g. feel psychologically safe, experience team member support, able to manage intra-team conflicts as well as nurture a moderate level of team cohesion). In addition, team members must be inspired to identify 
with a clear, specific set of collective (in this case Lean) cognitive goal(s) (e.g. commitment to the organizational Lean goals). All these dynamic human factors build upon and reinforce each other in a delicate balance; as was demonstrated in several of the reviewed studies. It takes considerable time and human effort to craft such Lean team 'ecosystems' and none of the single studies covered all (or even a majority or creative blend) of all the human dynamics indicated herein. In order to advance our understanding of these dynamics, such more comprehensive studies are highly recommended.

None of the studies reviewed did examine the degree of urgency felt by the team members for moving (effectively) towards Lean. Lean team members may be inspired to embrace Lean by the increasingly varied needs of the external and/or internal customers, but there may be other ways Lean team members are stimulated to start continuous improvement (Locke and Latham, 2002). Clearly, the roles and behaviors of (team) leaders in this respect have not yet been thoroughly scrutinized. According to DeChurch and Mesmer-Magnus (2010) all members of effective teams are assumed to 'act' in open-minded yet focused ways. Additionally, members of effective teams must have conflict-management skills as well as the will to inform each other in sufficient ways (instead of playing the 'information-is-power' game): both must be geared towards executing ambitious and explicit collective goals.

There is one particular type of employee behavior that seems to be crucial in a Lean team context, which has not been studied by Lean researchers at all. This behavior is known in small-group literature as voice behavior (LePine and Van Dyne, 1998; Morrison, WheelerSmith, and Kamdar, 2011) and it is defined as an "expression of constructive challenge with intent to improve rather than merely criticize" (LePine and Van Dyne, 1998: 854). Particularly in small Lean-type work teams, individual employees are found to speak up more easily to 'challenge the status quo' with the purpose of improvement instead of judging (LePine and Van Dyne, 1998). Morrison et al. (2011) postulates that the extent to which voice 
behavior takes place is affected by two beliefs: the employees' feeling that 'speaking up is safe in this team' and that 'other team members are capable of effective voice.' Beginner Lean team members must be trained to use their behavioral skill to give voice to their workrelated ideas with the intent of improving their team's performance. This kind of 'aid' in becoming a Lean team member seems necessary. If all people in a team are using voice instead of complaints, intimidation, gossip, etc. then such a team is quite differently than most. A positive team culture or climate, one in which voice takes place effectively is a kind of culture/climate most Lean scholars and practitioners and even non-Lean managers would want. Therefore, it is about the dynamics of becoming or staying such an effective team culture/climate that we will write next (see, also, Wilderom, 2011, as well as, e.g., Ford, Wilderom, and Capparella, 2008; Hatch, 2011; Schein, 2004; Spicer, 2011).

\section{TOWARDS MORE (EFFECTIVE) LEAN TEAM CULTURES/CLIMATES}

One may define organizational culture as a "fairly enduring multileveled, organized work context entailing the following: organizing values, norms, taken-for-granted assumptions, behavioral regularities, rituals, practices, procedures, patterns of discourse, use of symbols, ways identity is constructed" (Ashkanasy, Wilderom, and Peterson, 2011: 4). In everyday practice, only some teams or organizations succeed in congruently changing this set of features. Because of the high degree of interrelatedness of these features and the fact that they are so all-encompassing, the change conditions in place - also for single teams - seem largely top-managerial in nature. It is well-documented though that organizational culture change efforts on the part of top management normally go slow and often fail (Jorritsma and Wilderom, 2012; Mackelprang and Nair, 2010). One explanation is top managers' overconfidence, evidenced in their failing to see inadequacies in ('selling') their own plans (Shipman and Mumford, 2011). 
The question then is: what enablers need to be in place, including those residing within a given team culture, to facilitate effective Lean team cultures? There is a noteworthy absence of studies on the self-moving of a given team culture into Lean. Kekäle, Fecikova and Kitaigorodskaia (2004) have already noted that if a company seeks to implement Lean principles, its approach may need to differ among its various departments and teams, in order to accommodate the various existing subcultures (see, also, Detert, Schroeder, and Mauriel, 2000). Even in organizational cultures that are considered to be strong, there are reports of cultural differences between subgroups (Adkins and Caldwell, 2004; see also Bryson, 2008). The lack of scholarly attention to the existence of lower-level organizational subcultures (Hofstede, 1998) underscores how limited our current theoretical understanding of a Lean team culture is. This weakness is compounded by the fact that the great majority of Lean studies focus on organizational (or even industrial or national) level Lean culture or behaviors. Clearly, we need a greater understanding of these work-team level cultures. Moving a given team constellation or regime into an effective Lean team culture invariably involves a complex interplay of the enablers. Within the strategic boundaries set by higherlevel leaders, the team develops certain human dynamics. The exact process or sequence of how these dynamics evolve will differ from team to team (Aloini, Martini, and Pellegrini, 2011), since each has its own team culture as a starting point. As we have seen, what is crucial are the ways in which enabling (leader) practices are deployed and come across in the eyes of non-managerial work team members, i.e. the perceived sincerity with which the strategy gets implemented by higher and lower level leaders. Scholars often argue that team culture evolves only gradually over time, being subject to external forces such as mergers, new operators who join a team, stakeholders' opinions, or (team) leaders' behaviors (Hatch, 2011; Schein, 2004; Spicer, 2011). True cultural change on the team level takes place after (in part intuitive) reflection (on the new exogenous and endogenous forces) on the part of both 
team members and team leaders (see also Howard-Grenville, Golden-Biddle, Irwin, and Mao, 2011).

The evolvement of a Lean team culture involves a team with an adequate level of team performance. Over the course of its existence this idealized team has (or is) a set of values, norms, rituals, behaviors, practices, etc. (i.e., a team culture). The degree to which Lean team dynamics can evolve endogenously is intriguing, and as far as we know to date never been reported on. In line with the team-effectiveness literature, we categorized the nine human dynamics into three categories: affective, behavioral, or cognitive (see, e.g., Bosch-Sijtsema et al., 2011; DeChurch and Mesmer-Magnus, 2010; Ilgen et al., 2005; Kozlowski and Ilgen, 2006; Marks et al., 2001; Salas, Cooke et al., 2008). A team's change is surely to begin the moment that their organization's Lean strategy is being introduced. If an (even slightly) altered state-of-affairs shows team members that Lean is beneficial, Lean gets reinforced and later more firmly entrenched. In other words, Lean team performance improvements, including the perhaps slightly felt improvements on the part of key employees, may help to embed the Lean values, norms, rituals, behaviors, and practices into the more deeply rooted team culture. Hence it may take a while before a team has engaged in the deeper internalization of the Lean mindset. The culture-change process described herein has a strong affinity with the process of climate change. Team climate has a transient, team mood-state of nature. Hence, a team's climate change is likely to have begun already the first moment Lean's enablers are being introduced. In other words, a Lean team's climate is affected even before Lean team dynamics are in full bloom. It seems reasonable in this circumstance to speak of 'climcult' change (Schneider, Ehrhart, and Macey, 2011a, 2011b); effectively becoming a Lean team in the long term requires iterative reflection about both visible (e.g., available resources) and more tacit (e.g., habits and norms) organizing ingredients: carried out by reflecting and improvising, goal-driven team members and their leaders. This will facilitate 
the development of positive Lean team dynamics, which in turn anchors Lean work habits in a team's culture.

In sum, managers can indeed not manage, but merely facilitate, or enable, the selfevolvement of a Lean team's culture and climate. In other words, the members of the Lean teams themselves affect their climate and culture by reflecting on and slightly modifying their culturally-rooted team dynamics on a day-to-day basis (see Howard-Grenville et al., 2011). The degree to which they are effective in doing so depends to some extent on how higher managers enable their change initiatives. This enabling mode is markedly different from managing culture change in a team; we believe that culture change cannot be completely managerially controlled. Organizational members will not easily let go of their self-crafted practices, beliefs and values (Schein, 1990); resistance will be especially evident if they feel excessively or irrationally forced by their managers. Some firms have applied tools to enable a constant-change culture in favor of Lean, see for instance the various tools noted by Anand et al. (2009): visually appealing dashboards, value stream mapping and workshops with managers. And the more advanced Lean firms have internalized an efficient mindset to such a degree that they may not even formally label their way of working as Lean (Bessant et al., 2001). Similarly, the principles of the Toyota Production System have been incrementally developed over several decades and as a result are deeply ingrained into the DNA of its workers (Holweg, 2007; Spear and Bowen, 1999). A Lean team culture is thus crafted when team members change their own work practices or basic beliefs and values through voluntarily participating in a learning or improvising process, which may be enabled by the goal to have Lean practices (Santos-Vijande and Álvarez-González, 2007). In other words, a Lean team culture is hand-crafted through a continuous joint effort of both higher-level leaders, team leaders and team members (see also Ford et al,. 2008). Thus, achieving longterm operational excellence within teams at the bottom of organizational pyramids is a path 
that takes both determination, investment resources and a long-term view. An equally enduring or longitudinal, mixed-methods type of Lean team research trajectory in this vein is recommended.

\section{FUTURE RESEARCH AND REFLECTION}

Although we applied strict journal-grade type criteria with regard to the academic quality of the selected studies, the sample include predominantly qualitative case studies. Rothenberg's (2003) NUMMI case, for instance, provided a narrative on how Lean work practices were employed on the shop floor. We had expected more academic rigor in these Lean studies; we do need much more conceptual rigor as well as richer detail in the hypotheses and in the reporting of the used methods. This would lift the entire field. Also, there is a lack of longitudinal, hypothesis-testing Lean team study; we would especially welcome more studies such as the study of Mullarkey, Jackson and Parker (1995). Given the near absence of behavioral Lean research at present, we still know very little about the patterns of behavioral dynamics operating over time in high-performing Lean teams. This was one of the main reasons why, in this paper, we also leaned on team-effectiveness literature, amongst others: for purposes of further strengthening the ground for our propositions. Naturally, other theoretical content, such as that on small groups, team learning, team climate, and team identity, would contribute to refining or juxtaposing some of the assumptions and propositions resulting from the current review. For example, we might question the extent to which Lean team studies' findings are unique to Lean teams; highly performing Lean teams may have a different 'cultural content' (Ford et al., 2008) than comparable non-Lean teams. Exactly which cultural content of Lean teams differs significantly from similar non-Lean teams remains to be seen. 
The ways in which Lean studies assessed team performance is another clear point of future-research concern. Six of the ten studies actually measure performance, of which the most prominent measure is team members' 'job satisfaction' (see Godard, 2001; Jackson and Mullarkey, 2000; Mullarkey et al., 1995; Ooi et al., 2008). Other indicators of Lean team performance include: team learning orientation (Bunderson and Boumgarden, 2010); jobrelated strain (Jackson and Mullarkey, 2000); general strain, job-related anxiety, and jobrelated depression (Mullarkey et al., 1995); self-esteem, commitment, and motivation (Godard, 2001); and team competence (Kauffeld, 2006). Hence, performance is measured mainly from the employee perspective. The fact that none of the studies measure whether customers or other factors within the organization at large benefited in any way from the Lean implementation is remarkable, especially given that the studies were performed in for-profit firms in which Lean operational work is supposed to increase customer value, and none of the ten reviewed studies did query internal customers (i.e., those close to the focal teams, from whom it is easier to extract performance data). Thus, we urge scholars to take up this challenge and start collecting objective, team-level performance data, with measures such as productivity, efficiency, and (internal) customer satisfaction. This would lead to a more complete understanding of the effects of the human dynamics of Lean teams.

In summary, we reviewed the best available published studies of Lean operational work teams in commercial firms, focusing on effective human team dynamics. Moreover, as any movement of a firm or team toward the Lean ideology entails a climate and culture change, we included some insights into team culture and climate change. Given the paucity of rigorous empirical studies on changeovers toward or crafting Lean workplace team cultures and climates, there is an urgent need to conduct such longitudinal types of studies (Salas, Cooke et al., 2008). We call for in-depth studies that closely observe and codify a prospective change towards (a next phase in) Lean team cultures and climates. At present, there is a huge 
discrepancy between the numerously uttered pleas for culture change (even in strategy statements) and the number of actual field studies of the work floor teams becoming Lean. Systematic study showcasing those workplace teams that do proceed with their Lean journey (including those that seem to fail) will provide managers and change agents with valuable knowledge about successful Lean implementation. Ideally it would enable practitioners to improve their approaches and at the same time inform us about the empirical facts not easily seen with the naked eye. The study of Lean work-floor settings might, furthermore, uniquely aid in the forming of theory on how increasingly productive teams work: the moving holygrail target for many of us who care for sustainable and continuously improving work practices.

\section{REFERENCES}

Adkins, B., \& Caldwell, D. (2004). Firm or subgroup culture: Where does fitting in matter most? Journal of Organizational Behavior, 25(8): 969-978.

Aloini, D., Martini, A., \& Pellegrini, L. (2011). Effectiveness of different development paths in continuous improvement: Empirical results from a (new) methodological approach. International Journal of Technology Management, 55(1/2): 6-27.

Anand, G., Ward, P. R., Tatikonda, M. V., \& Schilling, D. A. (2009). Dynamic capabilities through continuous improvement infrastructure. Journal of Operations Management, 27(6): 444-461.

Ashkanasy, N. M., Wilderom, C. P. M., \& Peterson, M. F. (2011). Introduction to The Handbook of Organizational Culture and Climate, Second edition. In N. M. Ashkanasy, C. P. M. Wilderom \& M. F. Peterson (Eds.), The Handbook of Organizational Culture and Climate, Second ed.: 29-49. Thousand Oaks: SAGE Publications, Inc. 
Baer, M., \& Frese, M. (2003). Innovation is not enough: climates for initiative and psychological safety, process innovations, and firm performance. Journal of Organizational Behavior, 24(1): 45-68.

Ballé, M. (2005). Lean attitude. Manufacturing Engineer, 84(2): 14-19.

Barnes, C. M., Hollenback, J. R., Wagner, D. T., DeRue, D. S., Nahrgang, J. D., \& Schwind, K. M. (2008). Harmful help: The costs of backing-up behavior in teams. Journal of Applied Psychology, 93(3): 529-539.

Bartezzaghi, E., Corso, M., \& Verganti, R. (1997). Continuous improvement and inter-project learning in new product development. International Journal of Technology Management, 14(1): 116-138.

Bendoly, E., Croson, R., Goncalves, P., \& Schultz, K. (2010). Bodies of knowledge for research in behavioral operations. Production and Operations Management, 19(4): $434-452$.

Bessant, J., Caffyn, S., \& Gallagher, M. (2001). An evolutionary model of continuous improvement behaviour. Technovation, 21(2): 67-77.

Bicheno, J., \& Holweg, M. (2009). The Lean Toolbox: The Essential Guide to Lean Transformation (4th ed.). Buckingham: PICSIE Books.

Boer, H., \& Gertsen, F. (2003). From continuous improvement to continuous innovation: a (retro)(per)spective. International Journal of Technology Management, 26(8): 805827.

Bordia, P., Restubog, S. L. D., Jimmieson, N. L., \& Irmer, B. E. (2011). Haunted by the past: Effects of poor change management history on employee attitudes and turnover. Group \& Organization Management, 36(2): 191-222. 
Bosch-Sijtsema, P. M., Fruchter, R., Vartiainen, M., \& Ruohomäki, V. (2011). A framework to analyze knowledge work in distributed teams. Group \& Organization Management, 36(3): 275-307.

Bryson, J. (2008). Dominant, emergent, and residual culture: The dynamics of organizational change. Journal of Organizational Change Management, 21(6): 743-757.

Bunderson, J. S., \& Boumgarden, P. (2010). Structure and learning in self-managed teams: Why "bureaucratic" teams can be better learners. Organization Science, 21(3): 609624.

Busk Kofoed, L., Gertsen, F., \& Jørgensen, F. (2002). The role of CI and learning in an organisational change process: Experiences from a longitudinal study of organisational change. Integrated Manufacturing Systems, 13(3): 165-175.

Calantone, R. J., Cavusgil, S. T., \& Zhao, Y. (2002). Learning orientation, firm innovation capability, and firm performance. Industrial Marketing Management, 31(6): 515524.

Chin, W. W., Salisbury, W. D., Pearson, A. W., \& Stollak, M. J. (1999). Perceived cohesion in small groups: Adapting and testing the perceived cohesion scale in a small group setting. Small Group Research, 30(6): 751-766.

Cohen, S. G., \& Bailey, D. E. (1997). What makes teams work: Group effectiveness research from the shop floor to the executive suite. Journal of Management, 23(3): 239-290.

Day, D. V., Gronn, P., \& Salas, E. (2004). Leadership capacity in teams. The Leadership Quarterly, 15(6): 857-880.

De Dreu, C. K. W., \& Weingart, L. R. (2003). Task versus relationship conflict, team performance, and team member satisfaction: A meta-analysis. Journal of Applied Psychology, 88(4): 741-749. 
De Lange-Ros, D. J. (1999). Continuous Improvement in Teams: The (Mis)Fit Between Improvement and Operational Activities of Improvement Teams. Unpublished $\mathrm{PhD}$ thesis, University of Twente, Enschede.

De Lange-Ros, D. J., \& Boer, H. (2001). Theory and practice of continuous improvement in shop-floor teams. International Journal of Technology Management, 22(4): $344-$ 358.

DeChurch, L. A., Hiller, N. J., Murase, T., Doty, D., \& Salas, E. (2010). Leadership across levels: Levels of leaders and their levels of impact. The Leadership Quarterly, 21(6): 1069-1085.

DeChurch, L. A., \& Mesmer-Magnus, J. R. (2010). The cognitive underpinnings of effective teamwork: A meta-analysis. Journal of Applied Psychology, 95(1): 32-53.

Delbridge, R. (1995). Surviving JIT: Control and resistance in a Japanese transplant. Journal of Management Studies, 32(6): 803-817.

Detert, J. R., Schroeder, R. G., \& Mauriel, J. J. (2000). A framework for linking culture and improvement initiatives in organizations. Academy of Management Review, 25(4): $850-863$.

Edmondson, A. C. (1999). Psychological safety and learning behavior in work teams. Administrative Science Quarterly, 44: 350-383.

Edmondson, A. C. (2011). Strategies for learning from failure. Harvard Business Review, 89(4): $48-55$.

Edmondson, A. C., Dillon, J. R., \& Roloff, K. S. (2007). Chapter 6: Three perspectives on team learning. The Academy of Management Annals, Vol. 1: 269-314.

Elias, S. M. (2009). Employee commitment in times of change: Assessing the importance of attitudes towards organizational change. Journal of Management, 35(1): 37-55.

Emiliani, M. L. (1998). Lean behaviors. Management Decision, 36(9): 615-631. 
Ford, R. C., Wilderom, C. P. M., \& Caparella, J. (2008). Strategically crafting a customerfocused culture: An inductive case study. Journal of Strategy and Management, 1(2): 143-167.

Godard, J. (2001). High performance and the transformation of work? The implications of alternative work practices for the experience and outcomes of work. Industrial and Labor Relations Review, 54(4): 776-805.

Hackman, J. R. (1987). The design of work teams. In J. Lorsch (Ed.), Handbook of Organizational Behavior: 315-342. Englewood Cliffs, NJ: Prentice-Hall.

Hackman, J. R., \& Wageman, R. (1995). Total quality management: Empirical, conceptual, and practical issues. Administrative Science Quarterly, 40(2): 309-342.

Hatch, M. J. (2011). Material and meaning in the dynamics of organizational culture and identity with implications for the leadership of organizational change. In N. M. Ashkanasy, C. P. M. Wilderom \& M. F. Peterson (Eds.), The Handbook of Organizational Culture and Climate, Second ed.: 341-358. Thousand Oaks: SAGE Publications, Inc.

Hines, P., Found, P. A., Griffith, G., \& Harrison, R. (2008). Staying Lean: Thriving, Not Just Surviving. Cardiff: Lean Enterprise Research Centre.

Hines, P., Holweg, M., \& Rich, N. (2004). Learning to evolve: A review of contemporary lean thinking. International Journal of Operations \& Production Management, 24(10): 994-1011.

Hofstede, G. (1998). Identifying organizational subcultures: An empirical approach. Journal of Management Studies, 35(1): 1-12.

Holweg, M. (2007). The genealogy of lean production. Journal of Operations Management, 25(2): 420-437. 
Howard-Grenville, J., Golden-Biddle, K., Irwin, J., \& Mao, J. (2011). Liminality as cultural process for cultural change. Organization Science, 22(2): 522-539.

Ilgen, D. R., Hollenbeck, J. R., Johnson, M., \& Jundt, D. (2005). Teams in organizations: From input-process-output models to IMOI models. Annual Review of Psychology, 56: 517-543.

Imai, M. (1997). Gemba Kaizen (1 ed.). Deventer: Kluwer BedrijfsInformatie BV.

Jackson, P. R., \& Mullarkey, S. (2000). Lean production teams and health in garment manufacture. Journal of Occupational Health Psychology, 5(2): 231-245.

Jehn, K. A. (1997). A qualitative analysis of conflict types and dimensions in organizational groups. Administrative Science Quarterly, 42(3): 530-557.

Jorritsma, P. Y., \& Wilderom, C. P. M. (2012). Failed culture change aimed at more service provision: A test of three agentic factors. Accepted for publication in the Journal of Organizational Change Management.

Kanji, G. K. (2008). Leadership is prime: How do you measure leadership excellence? Total Quality Management, 19(4): 417-427.

Kauffeld, S. (2006). Self-directed work groups and team competence. Journal of Occupational and Organizational Psychology, 79(1): 1-21.

Kekäle, T., Fecikova, I., \& Kitaigorodskaia, N. (2004). To make it 'total': Quality management over subcultures. Total Quality Management, 15(8): 1093-1108.

Kozlowski, S. W. J., \& Ilgen, D. R. (2006). Enhancing the effectiveness of work groups and teams. Psychological Science in the Public Interest, 7(3): 77-124.

LePine, J. A., \& Van Dyne, L. (1998). Predicting voice behavior in work groups. Journal of Applied Psychology, 83(6): 853-868.

Liker, J. K., \& Morgan, J. M. (2006). The Toyota way in services: The case of lean product development. Academy of Management Perspectives, 20(2): 5-20. 
Locke, E. A., \& Latham, G. P. (2002). Building a practically useful theory of goal setting and task motivation: A 35-year odyssey. American Psychologist, 57(9): 705-717.

Mackelprang, A. W., \& Nair, A. (2010). Relationship between just-in-time manufacturing practices and performance: A meta-analytic investigation. Journal of Operations Management, 28(4): 283-302.

Marks, M. A., Mathieu, J. E., \& Zaccaro, S. J. (2001). A temporally based framework and taxonomy of team processes. Academy of Management Review, 26(3): 356-376.

Mathieu, J., Maynard, M. T., Rapp, T., \& Gilson, L. (2008). Team effectiveness 1997-2007: A review of recent advancements and a glimpse into the future. Journal of Management, 34(3): 410-476.

Maznevski, M. L., \& Chudoba, K. M. (2000). Bridging space over time: Global virtual team dynamics and effectiveness. Organization Science, 11(5): 473-492.

Moorhead, G., Neck, C. P., \& West, M. S. (1998). The tendency toward defective decision making within self-managing teams: The relevance of groupthink for the 21 st century. Organizational Behavior and Human Decision Processes, 73(2/3): 327-351.

Morgeson, F. P., DeRue, D. S., \& Karam, E. P. (2010). Leadership in teams: A functional approach to understanding leadership structures and processes. Journal of Management, 36(1): 5-39.

Morrison, E. W., Wheeler-Smith, S. L., \& Kamdar, D. (2011). Speaking up in groups: A cross-level study of group voice climate and voice. Journal of Applied Psychology, 96(1): 183-191.

Mullarkey, S., Jackson, P. R., \& Parker, S. K. (1995). Employee reactions to JIT manufacturing practices: A two-phase investigation. International Journal of Operations \& Production Management, 15(11): 62-79. 
Ooi, K.-B., Arumugam, V., Teh, P.-L., \& Chong, A. Y.-L. (2008). TQM practices and its association with production workers. Industrial Management \& Data Systems, 108(7): 909-927.

Quick, J. C., Cooper, C. L., Gibbs, P. C., Little, L. M., \& Nelson, D. L. (2010). Positive organizational behavior at work. International Review of Industrial and Organizational Psychology, 25: 253-291.

Rhoades, L., \& Eisenberger, R. (2002). Perceived organizational support: A review of the literature. Journal of Applied Psychology, 87(4): 698-714.

Rothenberg, S. (2003). Knowledge content and worker participation in environmental management at NUMMI. Journal of Management Studies, 40(7): 1783-1802.

Rovio, E., Eskola, J., Kozub, S. A., Duda, J. L., \& Lintunen, T. (2009). Can high group cohesion be harmful? A case study of a junior ice-hockey team. Small Group Research, 40(4): 421-435.

Salas, E., Cooke, N. J., \& Rosen, M. A. (2008). On teams, teamwork, and team performance: Discoveries and developments. Human Factors, 50(3): 540-547.

Salas, E., DiazGranados, D., Klein, C., Burke, C. S., Stagl, K. C., Goodwin, G. F., et al. (2008). Does team training improve team performance? A meta-analysis. Human Factors, 50(6): 903-933.

Salas, E., Sims, D. E., \& Burke, C. S. (2005). Is there a "Big Five" in teamwork? Small Group Research, 36(5): 555-599.

Salas, E., Stagl, K. C., \& Burke, C. S. (2004). 25 years of team effectiveness in organizations: Research themes and emerging needs. International Review of Industrial and Organizational Psychology, 19: 47-92. 
Santos-Vijande, M. L., \& Álvarez-González, L. I. (2007). Innovativeness and organizational innovation in total quality oriented firms: The moderating role of market turbulence. Technovation, 27(9): 514-532.

Schein, E. H. (1990). Organizational culture. American Psychologist, 45(2): 109-119.

Schein, E. H. (2004). Organizational Culture and Leadership (3rd ed.). San Francisco: Jossey-Bass.

Schneider, B., Ehrhart, M. G., \& Macey, W. H. (2011a). Organizational climate research: Achievements and the road ahead. In N. M. Ashkanasy, C. P. M. Wilderom \& M. F. Peterson (Eds.), The Handbook of Organizational Culture and Climate, Second ed.: 29-49. Thousand Oaks: SAGE Publications, Inc.

Schneider, B., Ehrhart, M. G., \& Macey, W. H. (2011b). Perspectives on organizational climate and culture. In S. Zedeck (Ed.), APA Handbook of Industrial and Organizational Psychology, Vol. 1: 373-414. Washington D.C.: American Psychology Association.

Seers, A. (1989). Team-member exchange quality: A new construct for role-making research. Organizational Behavior and Human Decision Processes, 43(1): 118-135.

Shah, R., \& Ward, P. T. (2003). Lean manufacturing: Context, practice bundles, and performance. Journal of Operations Management, 21(2): 129-149.

Shah, R., \& Ward, P. T. (2007). Defining and developing measures of lean production. Journal of Operations Management, 25(4): 785-805.

Shingo, S. (2007). Kaizen and the Art of Creative Thinking: The Scientific Thinking Mechanism (English translation ed.). Bellingham: Enna Products Corporation. Shipman, A. S., \& Mumford, M. D. (2011). When confidence is detrimental: Influence of overconfidence on leadership effectiveness. The Leadership Quarterly, 22(4): 649665. 
Shook, J. (2010). How to change a culture: Lessons from NUMMI. MIT Sloan Management Review, 51(2): 63-68.

Siemsen, E., Roth, A. V., Balasubramanian, S., \& Anand, G. (2009). The influence of psychological safety and confidence in knowledge on employee knowledge sharing. Manufacturing \& Service Operations Management, 11(3): 429-447.

Spear, S. J., \& Bowen, H. K. (1999). Decoding the DNA of the Toyota Production System. Harvard Business Review (September-October), 97-106.

Spicer, D. P. (2011). Changing culture: A case study of a merger using cognitive mapping. Journal of Change Management, 11(2): 245-264.

Stewart, T. A., \& Raman, A. P. (2007). Lessons from Toyota's long drive. Harvard Business Review, 85(7/8): 74-83.

Tekleab, A. G., Quigley, N. R., \& Tesluk, P. E. (2009). A longitudinal study of team conflict, conflict management, cohesion, and team effectiveness. Group \& Organization Management, 34(2): 170-205.

Tucker, A. L., Edmondson, A. C., \& Spear, S. (2002). When problem solving prevents organizational learning. Journal of Organizational Change Management, 15(2): 122137.

Uitdewilligen, S., Waller, M. J., \& Zijlstra, F. R. H. (2010). Team cognition and adaptability in dynamic settings: A review of pertinent work. International Review of Industrial and Organizational Psychology, 25: 293-353.

Van Dyck, C., Frese, M., Baer, M., \& Sonnentag, S. (2005). Organizational error management culture and its impact on performance: A two-study replication. Journal of Applied Psychology, 90(6): 1228-1240. 
Wilderom, C.P.M. (2011). Toward positive work cultures and climates. In N. M. Ashkanasy, C. P. M. Wilderom \& M. F. Peterson (Eds.), The Handbook of Organizational Culture and Climate, Second ed.: 77-85. Thousand Oaks: SAGE Publications, Inc.

Williams, H. M., Parker, S. K., \& Turner, N. (2010). Proactively performing teams: The role of work design, transformational leadership, and team composition. Journal of Occupational and Organizational Psychology, 83(2): 301-324.

Wolfswinkel, J. F., Furtmueller, E., \& Wilderom, C. P. M. (in press). Using grounded theory as a method for rigorously reviewing literature. European Journal of Information Systems.

Womack, J. P., \& Jones, D. T. (2003). Lean Thinking: Banish Waste and Create Wealth in Your Corporation. New York: Simon \& Schuster.

Wouters, M. J. F., \& Wilderom, C. P. M. (2008). Developing performance-measurement systems as enabling formalization: A longitudinal field study of a logistics department. Accounting, Organizations and Society, 33(4/5): 488-516.

Zaccaro, S. J., Rittman, A. L., \& Marks, M. A. (2001). Team leadership. The Leadership Quarterly, 12(4): 451-483.

Zeitz, G., Johannesson, R., \& Ritchie, J. E. J. (1997). An employee survey measuring total quality management practices and culture: Development and validation. Group $\boldsymbol{\&}$ Organization Management, 22(4): 414-444.

Zu, X., Robbins, T. L., \& Fredendall, L. D. (2010). Mapping the critical links between organizational culture and TQM/Six Sigma practices. International Journal of Production Economics, 123(1): 86-106. 
TABLE 1. The Set of Ten Analyzed Empirical Lean Team Studies

\begin{tabular}{|c|c|c|c|c|}
\hline Author (Year) & $\begin{array}{l}\text { Dependent } \\
\text { Variables }\end{array}$ & $\begin{array}{l}\text { Sample Size and } \\
\text { Type }\end{array}$ & $\begin{array}{l}\text { Methods } \\
\text { Employed }\end{array}$ & Key Findings \\
\hline $\begin{array}{l}\text { 1. Bunderson } \\
\text { and } \\
\text { Boumgarden } \\
\text { (2010) }\end{array}$ & Team learning & $\begin{array}{l}40 \text { teams, incl. } \\
228 \text { production } \\
\text { team members, } \\
81 \text { supervisors } \\
\text { and engineering } \\
\text { managers }\end{array}$ & Survey & $\begin{array}{l}\text { Psychological safety does not } \\
\text { relate to team learning. Team } \\
\text { structure positively affects team } \\
\text { learning. }\end{array}$ \\
\hline $\begin{array}{l}\text { 2. Ooi, } \\
\text { Arumugam, } \\
\text { The and } \\
\text { Chong (2008) }\end{array}$ & $\begin{array}{l}\text { Production } \\
\text { workers' job } \\
\text { satisfaction }\end{array}$ & $\begin{array}{l}173 \text { production } \\
\text { workers }\end{array}$ & Survey & $\begin{array}{l}\text { Organizational culture and } \\
\text { teamwork positively affect } \\
\text { production workers' job } \\
\text { satisfaction. }\end{array}$ \\
\hline $\begin{array}{l}\text { 3. Kauffeld } \\
(2006)\end{array}$ & Team competence & $\begin{array}{l}459 \text { workers in } \\
44 \text { self-directed } \\
\text { production } \\
\text { groups and } 39 \\
\text { traditional } \\
\text { production } \\
\text { groups }\end{array}$ & $\begin{array}{l}\text { Videotaped } \\
\text { optimiza- } \\
\text { tion group } \\
\text { task, survey } \\
\text { to assess } \\
\text { team design }\end{array}$ & $\begin{array}{l}\text { Self-directed work teams are } \\
\text { more competent when solving an } \\
\text { optimization task than traditional } \\
\text { work groups. }\end{array}$ \\
\hline $\begin{array}{l}\text { 4. Rothenberg } \\
\text { (2003) }\end{array}$ & $\begin{array}{l}\text { Employee } \\
\text { participation in } \\
\text { environmental } \\
\text { management }\end{array}$ & 55 employees & $\begin{array}{l}\text { Interviews, } \\
\text { 4-week field } \\
\text { observation, } \\
\text { document } \\
\text { study }\end{array}$ & $\begin{array}{l}\text { Role of specialist staff is critical } \\
\text { for environmental improvements; } \\
\text { they support worker participation. } \\
\text { A culture of collaboration and } \\
\text { trust enables this behavior. }\end{array}$ \\
\hline $\begin{array}{l}\text { 5. Bessant, } \\
\text { Caffyn and } \\
\text { Gallagher } \\
\text { (2001) }\end{array}$ & $\begin{array}{l}\text { Development of } \\
\text { continuous } \\
\text { improvement }\end{array}$ & $\begin{array}{l}\text { Various teams in } \\
6 \text { firms }\end{array}$ & $\begin{array}{l}\text { Action } \\
\text { research on } \\
\text { particular CI } \\
\text { issues }\end{array}$ & $\begin{array}{l}\text { Developing CI is an evolutionary } \\
\text { process. Nine routines need to be } \\
\text { developed in a firm for this } \\
\text { purpose. }\end{array}$ \\
\hline $\begin{array}{l}\text { 6. Godard } \\
\text { (2001) }\end{array}$ & $\begin{array}{l}\text { Work experience } \\
\text { (e.g. workload and } \\
\text { stressfulness), and } \\
\text { Outcomes (e.g. job } \\
\text { satisfaction, and } \\
\text { citizenship } \\
\text { behavior) }\end{array}$ & $\begin{array}{l}508 \text { randomly } \\
\text { selected } \\
\text { Canadian } \\
\text { workers }\end{array}$ & $\begin{array}{l}\text { Telephone } \\
\text { survey }\end{array}$ & $\begin{array}{l}\text { Traditional, supervised groups } \\
\text { have more positive worker } \\
\text { outcomes than 'high- } \\
\text { performance' models such as } \\
\text { Lean, team, and post-Lean forms } \\
\text { of organization. }\end{array}$ \\
\hline $\begin{array}{l}\text { 7. Jackson and } \\
\text { Mullarkey } \\
(2000)\end{array}$ & $\begin{array}{l}\text { Psychological } \\
\text { wellbeing }\end{array}$ & $\begin{array}{l}556 \text { production } \\
\text { workers }\end{array}$ & Survey & $\begin{array}{l}\text { Work demands significantly } \\
\text { affect worker's psychological } \\
\text { wellbeing. Social support } \\
\text { significantly affects workers' job } \\
\text { satisfaction. }\end{array}$ \\
\hline $\begin{array}{l}\text { 8. Zeitz, } \\
\text { Johannesson } \\
\text { and Ritchie Jr. } \\
\text { (1997) }\end{array}$ & $\begin{array}{l}\text { Total Quality } \\
\text { Management } \\
\text { practices and } \\
\text { culture }\end{array}$ & $\begin{array}{l}288 \text { production } \\
\text { workers, } \\
123 \text { service } \\
\text { workers, } \\
475 \text { employed } \\
\text { Master students }\end{array}$ & Survey & $\begin{array}{l}\text { All TQM practices and culture- } \\
\text { related aspects improve } \\
\text { significantly in more advanced } \\
\text { TQM program levels, except for } \\
\text { 'social cohesion' and 'trust:' that } \\
\text { remained at medium levels. }\end{array}$ \\
\hline $\begin{array}{l}\text { 9. Delbridge } \\
\text { (1995) }\end{array}$ & $\begin{array}{l}\text { Development of } \\
\text { workplace relations } \\
\text { between } \\
\text { management and } \\
\text { workers }\end{array}$ & $\begin{array}{l}\text { Production } \\
\text { workers and } \\
\text { team leaders }\end{array}$ & $\begin{array}{l}\text { Participant } \\
\text { observation }\end{array}$ & $\begin{array}{l}\text { Team leaders effectively speed- } \\
\text { up the change process. Peer } \\
\text { pressure in JIT teams undermines } \\
\text { the collective goals and raise } \\
\text { intra-team conflicts. }\end{array}$ \\
\hline $\begin{array}{l}\text { 10. Mullarkey, } \\
\text { Jackson and } \\
\text { Parker (1995) }\end{array}$ & $\begin{array}{l}\text { Individual } \\
\text { autonomy, Team } \\
\text { autonomy, Job } \\
\text { demands, Group } \\
\text { climate, } \\
\text { Psychological } \\
\text { wellbeing }\end{array}$ & $\begin{array}{l}65 \text { production } \\
\text { workers }\end{array}$ & $\begin{array}{l}\text { Longitudi- } \\
\text { nal survey }\end{array}$ & $\begin{array}{l}\text { The first implementation phase } \\
\text { has a positive effect on individual } \\
\text { autonomy, the second phase } \\
\text { positively affects group climate. }\end{array}$ \\
\hline
\end{tabular}

